\title{
Teaching English Online to Students With Autism Spectrum Disorder AND DOWN SYNDROME During The COVid-19 Pandemic
}

\author{
ENSEÑANZA DE INGLÉS EN LÍNEA A ESTUDIANTES CON TRASTORNO DEL ESPECTRO \\ AUTISTA Y SÍNDROME DE DOWN DURANTE LA PANDEMIA DE LA COVID-19 \\ ENSINO DE INGLÊS ON-LINE A ALUNOS COM TRANSTORNO DO ESPECTRO AUTISTA \\ E SÍNDROME DE DOWN DURANTE A PANDEMIA DA COVID-19
}

\section{Zoila Liliana Giraldo Martínez Professor, Universidad de Caldas, Manizales, Colombia. \\ liliana.giraldo@ucaldas.edu.co https://orcid. \\ org/0000-0001-7923-0471}

Sigrid Andrea Ramos Carvajal Professor, Universidad de Caldas, Manizales, Colombia. sigrid.ramos@ucaldas.edu.co https://orcid. org/0000-0002-1991-3294

\begin{abstract}
The unprecedented reality of the COVID-19 pandemic has led students and teachers to adapt to new routines and technological resources so that they can meet the pedagogical requirements generated by this world sanitary emergency. This case study explored a methodological intervention with students from an English school for special needs students in Manizales (Colombia). Our team of two university professors and seven pre-service teachers provided online English lessons to $17 \mathrm{stu}$ dents with autism spectrum disorder (ASD) and 13 with Down syndrome (DS). To do it, we used the principles of universal design for learning (UDL) and an eclectic method which combines strategies from thre specific approaches: The Presentation, Practice, and Production approach (PPP), the Treatment and Education of Autistic and Related Communication-Handicapped Children (TEACCH) approach and a behavioral management approach. The purpose of this study was to establish the impact of the implementation of such strategies on the English Language Learning (ELL) process of the ASD and DS learners. Three data collection techniques, including two surveys to parents and a researcher journal, were used. Findings indicated that: (a) the combination of various stimuli and methodological strategies from a variety of approaches enhanced learning, (b) the use of images and pictograms fostered memory, (c) setting clear routines promoted self-regulation skills, and (d) the families and students' challenges were turned into opportunities. It was concluded that teaching English online to ASD and DS students requires knowledge of their conditions and suitable strategies from an eclectic instructional approach.
\end{abstract}

Keywords: Autism spectrum disorder; Down syndrome; special educational needs; English teaching; ICT; COVID-19.

Received: 2021-02-28 / Accepted: 2021-06-15 / Published: 2021-09-11

https://doi.org/10.17533/udea.ikala.v26n3a13

Special issue on The Role of Technology in Language Teaching and Learning amid the Crisis Generated by the COVID-19 Pandemic. Editors: Marta González-Lloret, University of Hawai'i at Mānoa, USA; Laia Canals, Universitat Oberta de Catalunya, Spain; Jorge Pineda, Universidad de Antioquia, Colombia.

(C) 2021 Universidad de Antioquia. This is an open access article distributed under the terms of the Creative Commons License BY-NC-SA 4.0 International. 


\section{RESUMEN}

La realidad sin precedentes de la covid-19 ha llevado a estudiantes y profesores a adaptarse a nuevas rutinas y recursos tecnológicos con el fin de cumplir con los requerimientos pedagógicos generados por esta emergencia sanitaria mundial. El presente estudio de caso exploró una intervención metodológica con estudiantes de un instituto de inglés para estudiantes con necesidades educativas diversas en Manizales, Colombia. Nuestro equipo de dos profesores universitarios y siete docentes en formación impartió clases de inglés en línea a 17 estudiantes con trastorno del espectro autista (TEA) y 13 con síndrome de Down (SD). Con este fin, usamos los principios de diseño universal para el aprendizaje (UDL, en inglés) y un método ecléctico que combina estrategias de tres enfoques específicos: el enfoque de Presentación, Práctica y Producción (PPP), el Tratamiento y Educación de Niños con Autismo y Problemas Asociados de Comunicación (TEACCH, por sus siglas en inglés) y un método de manejo comportamental. El propósito del estudio fue establecer el impacto de la implementación de tales estrategias en el proceso de aprendizaje del idioma inglés (ELL) de los estudiantes con TEA y SD. Se utilizaron tres técnicas de recolección de datos, que incluyeron dos encuestas a padres y un diario de investigación. Los hallazgos indican que: a) la combinación de varios estímulos y estrategias metodológicas de una variedad de enfoques facilitó el aprendizaje, b) el uso de imágenes y pictogramas fomentó la memoria, c) el establecimiento de rutinas claras promovió las habilidades de autorregulación y d) los retos que enfrentan las familias y los estudiantes se convirtieron en oportunidades. Se concluyó que la enseñanza de inglés en línea a estudiantes con TEA y SD requiere el conocimiento de sus condiciones y estrategias adecuadas desde un enfoque educativo ecléctico.

Palabras claves: trastorno del espectro autista; síndrome de Down; necesidades educativas especiales; enseñanza del inglés; TIC; COVID-19.

\section{RESUMO}

A realidade inédita do Covid-19 tem levado alunos e professores a se adaptarem a novas rotinas e recursos tecnológicos para atender às necessidades pedagógicas geradas por essa emergência global de saúde. Este estudo de caso explorou uma intervenção metodológica com alunos de um projeto de ensino de inglês para alunos com necessidades educacionais diversas em Manizales, Colômbia. Nossa equipe de dois professores universitários e sete professores em treinamento ofereceu aulas de inglês online para 17 alunos com transtorno do espectro do autismo (TEA) e 13 com síndrome de Down (SD). Para isso, utilizamos os princípios do Design Universal para a Aprendizagem (UDL, em inglês) e um método eclético que combina estratégias de três abordagens específicas: o modelo de Apresentação, Prática e Produção (PPP), o modelo Tratamento e Educação de Crianças com Autismo e Problemas de Comunicação Associados (TEACCH, em inglês) e um método de gestão comportamental. O objetivo deste estudo foi estabelecer o impacto da implementação de tais estratégias no processo de aprendizagem da língua inglesa (ELL) de alunos com TEA e SD. Três técnicas de coleta de dados foram usadas, incluindo duas pesquisas com os pais e um diário de pesquisa. Os resultados indicam que: a) a combinação de vários estímulos metodológicos e estratégias de uma variedade de abordagens facilitou a aprendizagem, b) o uso de imagens e pictogramas promoveu a memória, c) o estabelecimento de rotinas claras promoveu habilidades de autorregulação, e d) os desafios para famílias e alunos se transformaram em oportunidades. Concluiu-se que o ensino de inglês online para alunos com TEA e SD requer o conhecimento de suas condições e estratégias adequadas a partir de uma abordagem educacional eclética.

Palavras chave: transtorno do espectro autista; síndrome de Down; necessidades educacionais especiais; ensino de inglês; TIC; COvID-19. 


\section{Introduction}

The field of special educational needs (SEN) has recently played an important role in Colombian education. Teaching English to students with SEN represents a challenge and commitment from institutions, teachers, support staff, and anyone else who deals with this target population. Therefore, it is imperative to search for the most suitable strategies for SEN students to reach their potential during the teaching and learning process. One tool that may facilitate this process is a methodological adaptation in the form of reasonable adjustments regarding English language learning (ELL) strategies, time and behavioral management, and working routines inside the school setting. The initiative of creating a project, named Escuela de Inglés para Estudiantes con Necesidades Educativas Diversas (EINED), emerged from the need of providing a new opportunity for students with SEN, from different municipalities, to learn a foreign language. Our purpose is to utilize an instructional approach which entails reasonable adjustments aiming at pupils with autism spectrum disorder (ASD) and Down syndrome (DS).

The purpose of EINED is to offer English classes virtually with an adapted methodology aiming to develop the four communicative skills in students with ASD or DS. Initially, having face to face classes was our goal, but because of the unprecedented emergency caused by the Covid-19 pandemic, our plan had to change unexpectedly. Thus, online English classes were the compulsory answer to such a complex situation, and we implemented our methodology online. Such a process has meant not only to include the adapted methodology but also to modify resources and materials by using technology. Teaching a foreign language to SEN students is a challenge itself, and addressing it virtually makes it even more demanding.

The main issue has been to find one English teaching method that could be adjusted to SEN students' needs since they require specific strategies according to their conditions. Other concerns relate to poor connectivity, low technological literacy, and students' short attention span which is aggravated by the extended use of their devices. This new venture came with the opportunity to employ the case study approach with those SEN pupils in order to explore a variety of methodological issues in real life as indicated by Crowe et al. (2011). The purpose of this case study is to utilize an instructional approach which entails a combination of reasonable adjustments from diverse methods when teaching English online to pupils with ASD and DS. This methodological article outlines a description of the context, participants, procedure, a literature review of ASD and DS conditions and an overview of the working method along with the analysis of findings and their implications. Moreover, at the end of this paper, we would like to suggest some possible teaching alternatives for English instructors who are working with learners with either ASD or DS.

\section{Theoretical Framework}

We would like to revise three main constructs in this section. Firstly, we will give a brief overview of the conditions of our students. Secondly, we will describe the principles of two approaches for planning and delivering our lessons. Finally, the concept of information, communication and technology (ICT) for students with SEN will also be reviewed.

\section{The Conditions}

This section describes ASD and DS, the main conditions that the students in this study presented.

\section{Autism Spectrum Disorder}

According to the Diagnostic and Statistical Manual of Mental Disorders (Autism Speaks, 2013), the subjects who have ASD present persistent difficulties in communication and social interaction in diverse contexts. Moreover, repetitive patterns and restricted interests or activities are manifested, and the development of their executive functions (ED) and self-regulation skills is seriously affected. Although they have a low 
working memory, they possess an excellent memory for areas of interest and for subjects they want to master. The majority of subjects with ASD have a photographic memory; therefore, they are able to remember a lot of information through visual stimuli. According to Steffie et al. (2020), when teaching students with ASD, it is important to remember that they have special educational needs. This means that, depending on their level of severity, ASD students can either be in special classrooms or mainstream ones where a variety of resources such as visual aids or special instruction can be provided. Fortunately, this latter inclusive model has increased over the last two decades in several countries including Colombia. However, as Lindsay et al. (2014) report, research has shown that educators still find teaching ASD students a challenging task, especially due to the heterogeneity they face when they have students with ASD along with neuro-typical students in their regular classrooms. That is why utilizing different strategies in inclusive classrooms is a must for every teacher. Lindsay et al. (2014), describe a number of ideas such as the use of visual aids, the management of time and routines, the setting of goals and rewards, the adaptation of spaces when in crisis, and the training of pupils about disability awareness.

The aforementioned techniques are a mandatory step to help ASD learners to engage actively in a regular classroom. Sparapani et al. (2016) conducted a study to measure the level of active classroom engagement in ASD students in elementary school. The results showed that measuring individual factors such as emotional regulation, classroom participation, social connectedness, and initiating communication, as well as flexibility, were the best ways to find out students' active engagement.

\section{Down Syndrome}

According to Amjad and Muhammad (2019), DS is "a genetic disorder which delays motor, language, and cognitive skills of an individual... Down syndrome is caused by the presence of abnormality in chromosomes, that is, 47 chromosomes rather than 46 are developed for some reason" (p. 128). Down syndrome is generally diagnosed at an early age, either before or after birth. The majority of individuals with DS are usually healthy. In some cases, there may be correlated issues with their mental health which can lead to a double diagnosis as autism spectrum disorder, which might appear in a $10 \%$ of the worldwide population with DS. However, that figure is likely to increase depending on the country of residence of the individuals with $\mathrm{DS}$.

Individuals with DS can thrive in any academic environment providing reasonable adjustments are put in place. In order to provide those modifications, Moreno and Tejada (2018) propose to focus the classroom intervention on four main areas: the objectives, the methodology, the activities and the evaluation. Studies have also shown that executive function (EF) has an impact on math, reading, and literacy performance in both DS and typically developing (TD) students. In addition, EF positively affects their ability to interact with their peers and to properly behave when performing a variety of tasks. Therefore, becoming aware of the relationship between EF and school performance may support methods to boost academic standards in learners with DS (Will et al., 2016).

From our participants with Ds, 3 students show severe oral communication problems, 4 lack motivation to develop their tasks, and 5 become easily distracted. Although the majority of them have problems with their working memory, suitable visual aids allow them to retain vocabulary effectively; hence the importance of using them in every single class.

\section{Teaching Approaches}

This section reviews three main teaching approaches: UDL, TEACCH, and ICT for SEN students. The following models not only comprise the pillars of our experience and the data analysis of our study, but also reflect the impact of the 
combination of such models on the SEN students' learning process.

\section{Universal Design for Learning (UDL)}

The UDL framework emphasizes three paramount principles: the why, the what, and the how of learning. In keeping with that framework CAST (2018) Guidelines suggest three pillars with their defined features:

1. Multiple Means of Engagement, which refers to offering students the opportunities to selfmotivate and regulate. It encompasses various engagement options that allow students to participate actively depending on their personality, capacities, background knowledge, culture, and neurological conditions.

2. Multiple Means of Representation, which deals with the possibility to provide numerous ways of suiting students' learning styles. Offering different options to approach the content is essential for students to comprehend the concepts and their connections.

3. Multiple Means of Action and Expression, which entails the development of communication skills and executive functions. Hence, taking into consideration the learners' capacities to express their knowledge, it is vital to provide them with various options so as to freely display what they have learnt.

In short, there is no one perfect model for learners to engage, represent, and express their understanding; but there are numerous methods that emerge from their individual differences. In our project we have integrated the three principles of UDL through activities, Information, Communication and Technology (ICT) tools, didactic resources, strategies, lesson plans, and online sessions. One of our goals is to generate awareness, equity, inclusion, and opportunities for the pupils and their families. Another goal is to provide our students with various ways to access learning in order to enhance their abilities.

\section{The Treatment and Education of Autistic and Related Communication Handicapped Children (TEACCH)}

This method is the first program of services not only for children and adults with ASD but also for individuals with other comparable developmental conditions and disorders (National Autistic Society [NAD], n.d.). To illustrate such a model, Taylor and Preece (2010) show how beneficial it was for them to use some aspects of TEACCH with students with multiple disabilities and visual impairment. The authors' findings confirm that there was an improvement in students' receptive and expressive communication as well as an increase in independent work. TEACCH involves promoting learning and development of people of all ages and skill levels. This method fosters various abilities such as independence as well as communication, social, and daily life skills. The purpose of TEACCH is to educate children in order to maximize their strengths taking into account their difficulties. In addition, acknowledging TEACCH values would also boost a sense of community and ASD awareness. For instance, as the National Autistic Society manifests, there are certain TEACCH values that must be recognized, namely, teaching, expanding, appreciating, collaborating and cooperating, and adopting a holistic approach aiming at the individuals, their families, and their community. Moreover, the method encourages students to develop a concept of achievement and teachers to individualize the students. To exemplify this, children with ASD and other conditions can learn together through the different daily activities which are programmed depending on their individual needs (Raising children.net.au, n.d.).

The educational techniques include: the development of visual information, spatial organization and flexible routines. Its components entail a structured teaching approach concerning the adaptation of facilities, working systems, agendas, and visual information (Cuadrado, 2006; Mulas et al., 2010). Taking into consideration the COVID-19 pandemic, 
we opted for implementing new ways of applying this approach during the online classes. This meant focusing more on the visual aids and agendas, timed and systematic working tasks, as well as flexible routines, which facilitates not only the learning of the target language but also the development of executive functions and self-regulation skills. The next section contains a more thorough explanation of the techniques used from this method.

\section{Information, Communication, and Technology for Students With SEN}

Although technology entails all aspects of modern life, the utilization of ICT tools is still incipient in our working context, let alone using such resources to teach students with SEN. Migliaresi (2018) affirms that technology "offers the opportunity to learn in different ways, visually, aurally, kinesthetically, but also it can provide information in ways that make it more accessible [...] that would be difficult to achieve in other ways" (para. 6). This refers to the use of a variety of technological tools with students with special educational needs in order to facilitate their access to education despite their condition. Technology in most cases becomes a great strategy to deal with challenging behavior as well since it enables the pupils to develop other abilities and look for different channels to engage themselves in the activities. Furthermore, technology offers the chance to get involved in online sessions and thus generate an arena for interaction and communication with their peers. Other skills that can be developed in the learning process are cooperation, problem-solving, and mutual respect. Competences that go further than the ICT knowledge (Magliaresi, 2018).

Another advantage of utilizing technology is to provide the students with multiple representations of knowledge which help students to retain all the acquired information received in their long-term memory. Therefore, "computerized learning environments may serve as more effective support tools for the instruction of SEN students precisely because they are characterized by multiple representations of knowledge" (Shamir \& Margalit, 2011, p. 279).
The explanation rests on the idea that each concept has a reciprocal relation making up for other needs the pupil may experience (Moreno \& Durán, 2004). It is well known that there is little research on the area of ICT when dealing with SEN students. Firstly, literature about this field is scarce, especially in Colombia. Secondly, having very few systematized experiences on this approach may not have permitted a major impact on research. Finally, the misconception of ICT being a hurdle has been an obstacle in the use of technology.

The emergency caused by the COVID-19 pandemic has urged educators, institutions, families, and students to concentrate their efforts on the quest to access knowledge through the use of technological tools. The reason for such a venture was that, during the lockdown decreed by the Colombian government in 2020, technological devices became the only means to make contact with others, and they also served as the bridge between both counterparts: students and teachers. Thus, our project with our SEN pupils had to adjust to this new reality in terms of planning, delivering our classes, creating and designing resources as well as using and adapting our methodology in order to meet our learners' needs. Although initially this experience represented a challenge for all of us, we have managed to accommodate to the new contingency.

\section{Method}

This project emerges from a personal experience of both researchers and their students in a very specific context: the virtual English classes taught at EINED, which is an extension project from a public university in Manizales, Colombia. This qualitative case study intends not only to understand the significance of a variety of ELT methods and the students' reactions to them but also their role in improving the conditions of students with SEN when learning English. This is a case study because it attempts to analyze a number of complex situations that may occur in their natural context in order to have a better appreciation of the facts. 
Case studies provide an opportunity to describe participants, methods, settings thoroughly and more naturally (Crowe et al., 2011). In them, data are collected through various techniques with the aim of having a more holistic approach when analyzing the information gathered.

\section{Participants}

EINED's team is composed of two professors, five support teachers, and a group of 30 students with ASD, DS, Attention Deficit Hyperactivity Disorder (ADHD), and Rett Syndrome, along with their families This population includes 19 students with ASD, out of which one pupil has a double diagnosis of ASD and ADHD. Among them, 14 pupils are diagnosed with ASD Level 1 (requiring support), 3 of them with Level 2 (requiring substantial support), and 2 with Level 3 (requiring very substantial support), as Figure 1 illustrates. Moreover, there is a learner diagnosed with Rett Syndrome who is the unique diagnosed case in Manizales, Caldas. Finally, there are also 9 students with moderate DS. Participants' ages range from 7 to 36 years old. Due to the level of severity of their conditions and the heterogeneity of their capacities, students show low working memory, attention deficit, and lack of self-regulation skills.

It is important to highlight that the standard of oral communication of some of our learners goes from verbal to very restricted as it is described in Figure 2. This implies that our instructional approach needs to suit the students' varied competences. In addition, while some of our students are literate, others are not, which means that the use of visual aids is beneficial for all students.

Another essential aspect is that this group of students with ASD requires constant support to develop the class activities; therefore, the accompaniment of their families is paramount. These families come from low to medium strata, leading to a disparity in terms of obtaining the necessary resources. In addition, their technological literacy differs a great deal which means that coping with technology and devices is not a simple task for some of them. Despite all these difficulties, the students and their families have become acquainted with the tools through their continuous use in class.

\section{Data Collection}

The first data collection technique was a needs analysis through a parent survey in which data about the students' preferred input for learning was gathered. This information was important because it gave the researchers useful insights about the way students learn best.

These data were used as an essential tool for planning the strategies and activities during the research process. The second instrument implemented was a researcher's diary. Here, the process of the classes was described in detail as well as analyzed and interpreted by the researchers so that some recurrent categories could emerge from such interpretations. This diary was useful to both collect their researchers' perceptions and have a better understanding of

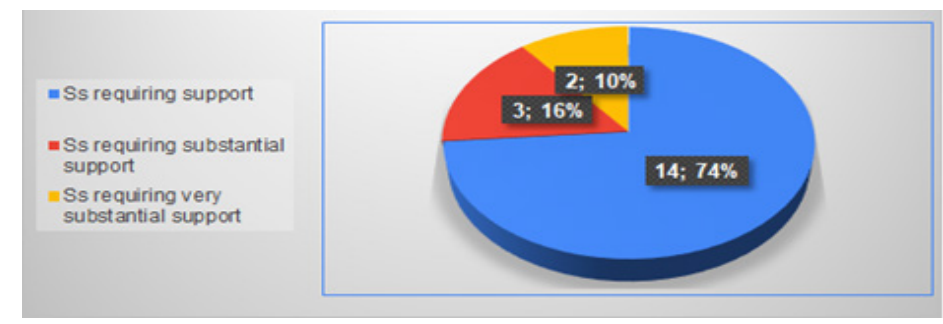

Figure 1 Severity Levels of ASD Students According to Support Needed 


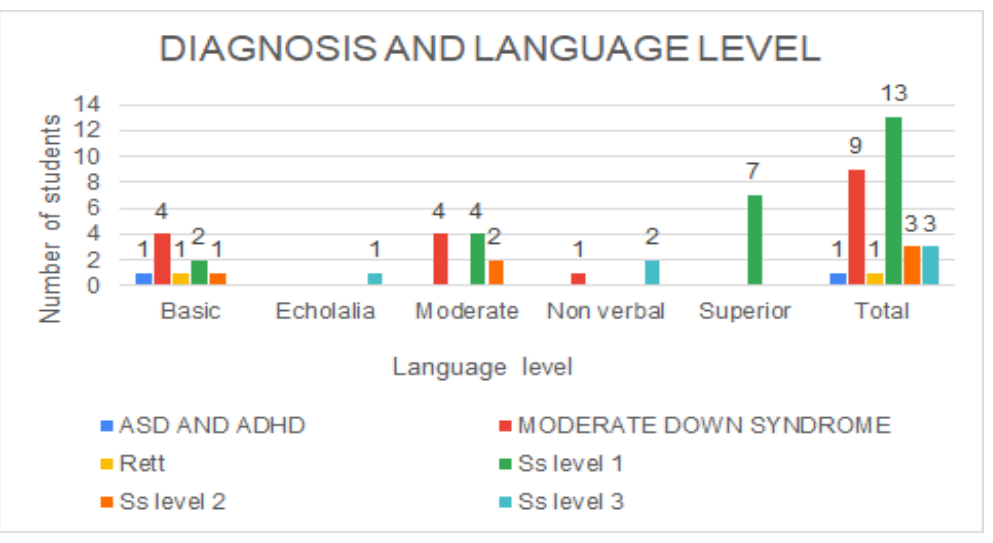

Figure 2 Diagnosis and Language Level

Note: The figure presents the total number of students' diagnosis and language level.

the process. The data collected through this instrument was also handy throughout the triangulation stage. The final data collection tool was a second survey for parents after the application of a variety of teaching methods in order to determine their usefulness and relevance. This tool was significant since it evidenced the SEN students' progress in the English language learning.

High ethical standards of research were followed by respecting the individual differences and dignity of the participants of the study. Additionally, the informed consent of the participants' parents was obtained before starting the research process. Also, the anonymity and confidentiality of the participants was maintained at all stages of the study. Finally, all the instruments administered were analyzed with honesty and transparency.

\section{Instructional Approach}

Before discussing our approach, it is important to remember that in order to achieve inclusion, institutions and teachers must focus on providing pupils with reasonable adjustments. This concept was coined by the World Health Organization (2011) when they emphasized the importance of putting in place a number of accommodations to suit the students' needs. In Colombia, the government decreed the adoption of a law that implies positive actions and reasonable adjustments (Colombia, Congreso de la República, 2013).

The first approach we utilized is the PPP, which comprises a structure of planning classes following specific stages leading to a clear progression and a way to favor anticipation and avoid anxiety. The presentation stage is the moment to display all the new information, vocabulary, and grammatical structures by means of multiple channels. It aims at activating students' schemata (Weller, 2019) or previous knowledge as well as introducing new concepts in context, breaking the complex language into smaller chunks (Pimentel et al., 2014). In the practice stage, the pupils had the chance to use what they had learnt in a semi - controlled environment. It is vital to remember that some SEN students might always need the teachers' assistance. However, such aid may diminish when the learner shows some signs of independence. The final stage is called production, a phase in which students were provided with activities in order to use the language more freely.

A second approach used was TEACCH which has been more commonly used as an intervention method for individuals with ASD. However, there is some evidence around the world that this model has been effective with individuals who 
have other conditions as well, although there is not much evidence of its use for English language teaching (ELT). Therefore, we used this approach with the SEN students in an attempt to find more strategies to ameliorate their SLA and cognitive development.

Since students with ASD and DS are predominantly visual (Lybarger, 2017; Ruiz, 2009) we focused on the design and adaptation of visual aids. We used augmentative and alternative communications systems (AACs) as a means of visual support. As stated by Burkhart (n. d.) for the International Society for Augmentative and Alternative Communication, AACS are "a set of tools and strategies that an individual uses to solve everyday communicative challenges" (para. 1). The Royal College of Speech and Language Therapists (2019) suggests that the AACs can include (a) gestures, (b) symbols: pictograms, photos, images, amongst others, (c) word boards, (d) books, and (e) voice output communication aids.

The pictograms used are downloaded freely either from a web page called ARASAAC or from a program called Picto Selector. Hart (2015) affirms that "for students with special needs, pictograms provide shortcuts to meaning" (p. 3). According to Hart, these tools can be considered a temporary support to motivate the students to utilize other resources such as the relationship among sound, letter, and context so as to recognize new words. Such pictograms are used in English and Spanish as a way to promote a supplementary aid in the acquisition of EFL. Cioè-Peña (2015) argues that the use of the native language should not be shown as an impediment but as an opportunity to incentivize the learning of various languages. Rodríguez (2016) points out that the EFL learning process of students with special needs can be successful in either their mother tongue or the target language; thus, she believes that the information can be addressed in both languages.

The pictograms were not modified but adapted to a format framed in red with a yellow filler and red words as seen in Figure 3. This method facilitates the reading of texts and the retention of vocabulary. A study carried out by Pan (2010) "showed that partial matches between Working Memory (WM) and attention displays could guide attention, while color had a stronger effect than shape did. This finding supports the idea that color can be more efficient than shape in biasing attention" (p. 127). In a previous year (Pan, 2009), the same author also highlighted that warm colors, like red, yellow, and orange undoubtedly have a higher effect on attention compared to cool colors such as brown and grey. Dzulkifli and Muhammad (2013) declare that the importance of color cannot be underestimated. In educational settings, for instance, color can be a motivating factor in the learning process as it facilitates the development of cognitive abilities which are paying attention, perceiving, remembering and understanding
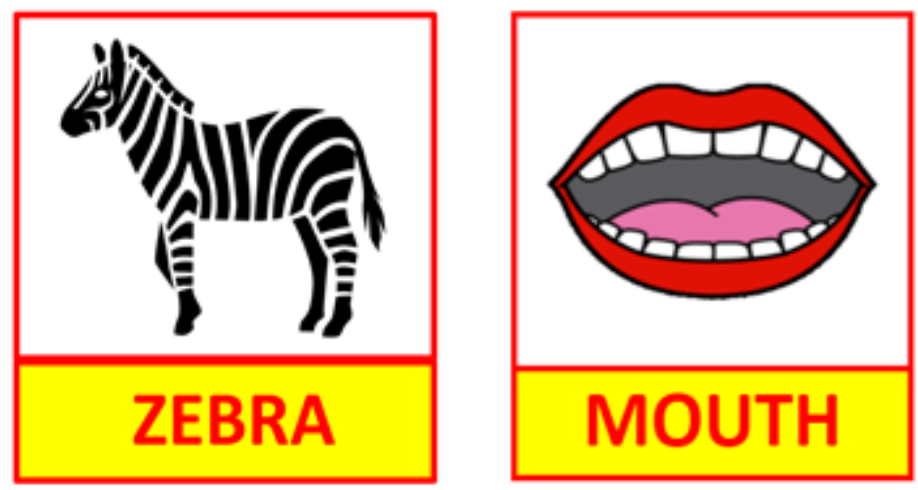

Figure 3 Example of Pictograms Used in the Presentation Stage. 
various kinds of information. Moreover, in clinical settings, studies have shown that color can be beneficial in patients with different conditions such as Alzheimer, dyslexia, and ASD since color can help them to grasp the learning programs more easily as colors have the potential to attract people's attention. Another important use of pictograms was the creation of visual agendas which supported the recognition of the class steps by students who were not able to read.

Another strategy used during this project was the adoption of class routines and set agendas. This technique was useful to fight anxiety and motor restlessness, and to benefit the development of skills. It was paramount to establish positive routines that helped the students to understand and predict the exact class steps and be ready to react to changes.

When providing students with a teaching structure, it was also needed to consider time and behavioral management. For SEN students, time is a paramount aspect. Hence, the use of a clock with beginning and finishing times increased students' attention span and reduced their agitation.

During this project it was vital for instructors to identify their learners' unique characteristics and particular abilities which defined them as individuals. Although they shared features of the condition, in this case ASD and DS, each pupil showed their own personality, beliefs, preferences, and thoughts. This meant that we provided them with the possibility to freely express their opinions concerning the activities being developed in our classes. Therefore, giving them constant positive feedback permitted them to have a feeling of achievement and comfort. We also took students' individual skills into consideration when they were required to complete a task since their outcomes were only measured by means of what they managed to do throughout the whole class.

Implementing strategies to favor the students' sensory integration was also paramount. One of the shared characteristics of students with ASD and
DS is the inability to process the sensory stimuli from their surroundings. By this term, we mean all the information received through the senses. As Lashno (n.d.) affirms, "information is processed through the brain. The brain then interprets, organizes, and directs the body to respond appropriately to that sensory information" (para. 2).

This instructional approach included a behavioral management technique. One of the useful methods implemented to manage students' behavior in the lessons was Brain Gym (BG). According to Spaulding et al. (2010), this technique mixes simple exercises and body movements to "remediate learning problems and help the subject reduce psychological and emotional stress" (p. 10). Vázquez (2020) also pointed out that BG helps to link the right and left-brain hemispheres, enhancing concentration and imagination as well as improving motor coordination which fosters understanding.

Additionally, a variety of interactive tools were used throughout the process. Firstly, every session was developed through the use of visual aids provided via Google« presentations. Secondly, we used an application called Jamboard ${ }^{\oplus}$ which facilitates the manipulation of images and language as well as the synchronous collaboration from students and instructors. Thirdly, interactive web pages and worksheets were a great tool for teaching SEN learners. Moreover, YouTube ${ }^{ø}$ videos and tutorials also played a meaningful role in the sessions. Online tutorials offered the opportunity to provide the SEN students with more detailed explanations and instructions, having the support of music, animation, and language. Finally, we used Excel $^{\circ}$ sheets to create and present games didactically since images and rules can be customized.

\section{Findings}

The findings emerged from this case study showed the impact of a variety of strategies implemented on the ELL online process of students with ASD and DS. Firstly, after administering the data collection instruments, namely, two parents 'surveys and a teacher's 
journal from each researcher, it can be concluded that the combination of various stimuli facilitate student's learning. Secondly, based on the data analysis, the students improved their executive function and self-regulation skills by means of the implementation of a variety of methodological strategies based on different approaches. Thirdly, the data collected showed that memory was fostered through the use of images and pictograms. Additionally, the interpretation of the instruments concluded that one way of promoting self-regulation skills is the setting of clear routines during the classes. Finally, information from the three data collection techniques explained how all the ICT challenges families and students had at the beginning of the study, became opportunities in the long run.

\section{Combining Visual, Auditory, and Kinesthetic Stimuli Facilitates Learning}

The data from the first parent survey revealed that visual stimuli was the preferred way of learning since 25 out of 30 students preferred to learn through images, graphs, and pictograms (Figure 3). The second most frequent way of learning was the combination of verbal instructions with images and the use of activities in which they had to deal with different materials (20/30). Finally, the least preferred kinds of input were songs and videos since only 8 parents chose this option.

It was evident that parents thought that their children learn best by using visual, auditory, and kinesthetic stimuli. Visual aids are advantageous since they facilitate the retention of vocabulary, enhance the concentration span, and allow the association of images with concepts. Moreover, the auditory resources help students reinforce the visual input with the notions to be learnt. Finally, kinesthetic activities are an asset to develop fine and gross motor skills; also, we can promote creativity and encourage motivation in our students. As journal entry N. 5 from one of the researchers illustrates, the core of the classes is not only teaching a foreign language, but also, developing a number of competences.
Journal entry N. 5 Researcher $\mathrm{A}^{1}$ : "The class is not just focused on learning English. Ss can also develop some creativity"- "One of the mothers said she and her son found this type of activity very good for concentration."

\section{Methodological Strategies Based on Multiple Approaches Enhance Learning}

The methodological strategies used in class provided students with the opportunities to learn via numerous approaches and foster their executive functions and self-regulation skills. The former ability "refers to our ability to put things we need to achieve in an order of hierarchy which impacts organization, planning, working memory, time management, and prioritization" (Lybarger, 2017, p. 4). Whereas the latter skills include the capacity to adjust to any circumstance and control their emotions and reactions by reducing the students' anxiety when coping with different contexts. Both researchers' journal entries display these aspects as follows:

Journal entry N. ${ }^{\circ}$ 4. Researcher A: "During the lesson, most of the Ss were smiling" / "Some parents said that their children were interested in today's class."

Journal entry N. ${ }^{\circ}$. Researcher B: "Although instructors called out some names to participate, some Ss did it voluntarily and spontaneously."

Journal entry N. ${ }^{\circ}$ 17. "He, using a doll (realia) pointed to a part of the body and the Ss said it. Some Ss were assisted by their parents. Afterwards, the Ss did an exercise using an online tool in which they had to drag a word (a part of the body) and put it in the right place on an image of a human body."

\section{Images and Pictograms Foster Memory}

Pictograms in L1 and L2 were used during all stages of the classes. They were a great tool since they present concepts and information in a simplified yet memorable way. It was noticeable that students with SEN had an ability to understand pictograms and associate them with words or concepts more easily and rapidly. In question N. 4 from a second

1 All entries are translations by the authors from Spanish. 
survey for parents, it was evident that for $83.3 \%$ of the families as shown in Figure 4, the use of images and pictograms was useful because "they facilitate and complement the English language learning. These resources suit the needs and the individual learning styles of the SEN population" (journal entry N. $\left.{ }^{\circ} 419\right)$.

Pictograms also facilitate the retention of vocabulary, especially when they are accompanied by words framed in bright colors. Pan (2010) reports that warm colors have a greater impact on memory than cool colors. As Dzulkifli and Muhammad (2013) state, color stimulates cognitive processes such as attention, memory and understanding. Evidence of this can be found in the following journal entry:

Journal entry N. ${ }^{\circ} 23$. Researcher A: "The students can remember words more easily when they are accompanied by pictograms" "The Ss can associate images to words easily" / "Images can stimulate memory."

In a parents "survey one of the parents expressed: "The color of the pictograms has helped my son to memorize more words, since I used to work with pictograms in black and white and he had a lot of difficulty to retain the words".

\section{Setting Clear Routines is Essential to Develop Self-Regulation Skills}

Since one of the characteristics of ASD and DS students is their inflexibility, we established clear routines through visual and written agendas in every class in order to accommodate the activities to suit this particular characteristic. Anticipation helped control anxiety and motor restlessness (Lybarger, 2017), and it enhanced the development of self-regulation skills. To exemplify, parents were asked about the impact of the strategies used in class in their children's life: Parent survey, Question 3: $¿$ Have the strategies used in the English classes had an impact in different areas of your child's life? If so, in which ones?

Most of the parents responded positively to this question, and they also reported examples of the impact generated in their children's life as follows: The first parent stated: "The strategies help them self - regulate". Another parent claimed: "The strategies used by the teachers help them with their concentration and attention". Another mother said: "The classes foster the students' wellbeing". Finally, one of the parents commented: "My son feels calmer during the classes

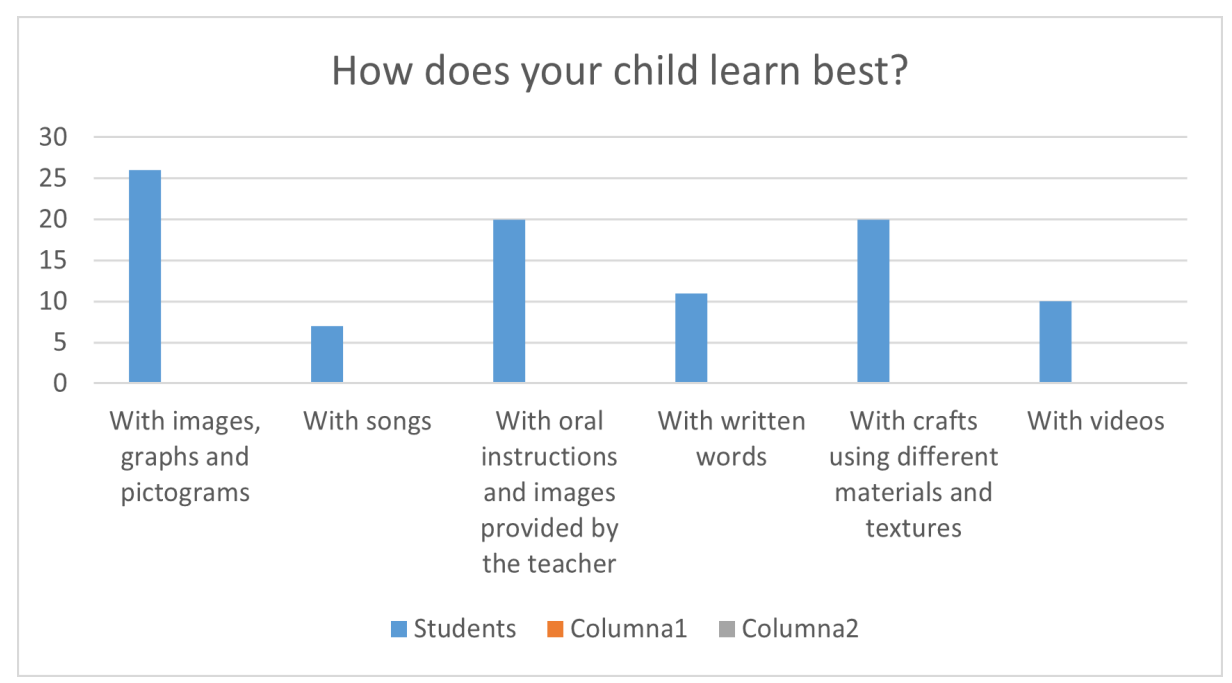

Figure 4 Students Preferred Input for Learning 
because he knows their structure very well since it is always the same". this is also shown in journal entry $\mathrm{N} .^{\circ} 16$ :

Researcher A says: "Class agenda for the day was presented in L1 and L2 and using pictograms. Then, the steps of the class were presented again in L2 using pictograms. Then, each step was presented again in L1 and L2 using more pictograms (...) Students seemed completely at ease with the structure of the class."

The excerpts from the researcher's journal evidenced the usefulness of agendas in both languages to reinforce the steps of the class and prioritize anticipation.

Another strategy which favored the development of self-regulation skills was the implementation of BG at the beginning of the classes as a preparation step for the process ahead. Vázquez (2020) states that using B G in class fosters concentration, attention and these factors facilitate learning, as seen in the following journal entry:

Journal entry N. 16. Researcher X: “Today, THE BG exercises were a success! The students were smiling and doing the exercises very well". Those exercises were motivating for the students since they felt relaxed and more alert to start the class."

Using BG offers several advantages. Firstly, learners seemed to enjoy the proposed exercises, and they expressed their joy whilst doing them. Secondly, BG enhances the development of their motor skills which leads to steady progress. Thirdly, it was noticeable that BG improved their behavior during the session. Additionally, the students had the opportunity to release the stress evidenced in their motor restlessness and were able to feel more self-confident in the completion of the activities.

\section{ICT Challenges Were Turned Into Opportunities}

As the study was carried out during online sessions through the Google Meet platform, different ICT tools were used. When the virtual sessions started, we thought it would be a huge challenge for the students and their families. However, gradually, various technological resources were introduced, and the learners and their families became more acquainted with this new reality. The following journal entries illustrate this fact:

Journal entry N. ${ }^{\circ} 17$. Researcher A: "little by little students and families became familiar with the use of live worksheets" - "Interactive tools have helped the students to associate and complement the topics studied in the lessons."

Journal entry N. ${ }^{\circ} 25$. Researcher A: "It was interesting to see how easy students and their families found ICT tools such as Jamboard and live worksheets."

\section{Discussion}

As stated by Crowe et al. (2011), the main objective of a case study is to examine a situation thoroughly in its inherent setting. Thus, this case study supports the latter concepts since various English teaching methods were analyzed in light of ELT online practices with ASD and DS students. Firstly, the main problem was to find one specific English teaching method that suited the needs of SEN learners based on their particular conditions. After implementing a set of strategies from a combination of ELT methods, we claim that there is not one perfect method for teaching English to this population. Instead, we argue that an eclectic instructional approach is the key to address SEN students from a multifaceted approach. This claim can be validated with the three pillars proposed by CAST (2018) guidelines which are multiple means of engagement, representation, action and expression. Despite the limitations originated by ASD and DS in terms of learning, these students have the potential to develop their communicative skills in English, especially listening and speaking.

Additionally, another issue that arose from this study was the scarce knowledge of ICT tools and devices from the part of students and their families in order to develop the activities of the online 
English lessons. Even though the use of technological resources was somewhat challenging for students and families who were not ICT literate, one unexpected result is that they are successfully coming to terms with these new virtual resources. Such aids represent a benefit since they provide different perspectives to access knowledge as stated by Migliaresi (2018). Furthermore, because of the synchronous characteristic of our sessions, students have been able to fully complete their ICT tasks along with the teachers' guidance in a more dynamic environment.

There was another matter regarding the short attention span ASD or DS students present. Having used a variety of strategies to develop self-regulation skills such as TEACCH and BG, we affirm that those techniques contribute to foster self-control and enhance readiness to learn in the proposed activities as Spaulding et al. (2010) affirm. Moreover, based upon the data collected, we claim that learning through visual stimuli helps our SEN students to focus their attention on the images and associate them with words or concepts, even if they are not able to read or write. The majority of our SEN learners have a photographic memory which facilitates their learning process as Lybarger (2017) states.

Additionally, since inflexibility is one of the difficult areas of ASD and DS, we have confirmed that keeping a strict agenda and following specific routines help these students diminish their anxiety triggers. However, it is paramount to provide them with slight routine changes to foster flexibility progressively.

One of the limitations we identified at the beginning of the process was the need for their families' constant support; however, such constraints became an opportunity as their families have been more involved in the sessions leading to generating a sense of community within the team. Moreover, we have been able to facilitate the development of independent activities which might gradually augment their autonomy.

\section{Conclusions}

Teaching English online to SEN students requires knowledge of the main features of the learners' conditions and the reasonable adjustments that can help them attain their full potential. In this methodological article, we examined an instructional approach with the aim of proposing several strategies to facilitate the acquisition of the foreign language ( $\mathrm{FL}$ ), the development of $\mathrm{EF}$ and self-regulation skills and the behavioral control of ASD and DS students.

We have described a number of techniques from three perspectives namely the 3Ps model, the TEACCH method and a behavioral approach based on BG. When implementing all these strategies we took into consideration the principles of UDL which, from our point of view, should be the SEN teaching foundations. We suggest the aforementioned approaches since we have realized the advantages arising from their implementation. Firstly, the 3Ps model helps ASD and DS pupils to reduce their anxiety triggers owing to its solid structure. Secondly, the TEACCH method provides a very complete set of classroom management techniques so as to meet SEN students' needs. Thirdly, the BG approach represents an appropriate manner to train the students in their behavioral management skills. Thus, we invite our colleagues to consider the mixture of multiple approaches which might be beneficial to their SEN learners in various developmental areas.

Even though we have found certain limitations, we have also encountered positive outcomes which have become our inspiration to offer a more suitable quality teaching process. Such an experience has led to our pupils' steady progress regarding the foreign language learning (FLL), their families' constant involvement as well as support and a better understanding of the ASD and DS conditions. According to the findings, we believe that our intervention may be relevant for teachers and students not only in times of the COVID-19 pandemic but also for regular online teaching practices. All in all, the 
most significant lesson we have learnt through this experience is that "teaching SEN students with compassion, love, and respect must be the key to fostering their desire for self-improvement."

\section{References}

Amjad, H. \& Muhammad, Y. (2019). Teaching students with Down Syndrome: Perspectives of special school teachers and psychologists. Journal of Inclusive Education, 3(1), 127-143.

Autism Speaks (2013). Autism Diagnosis Criteria —dms5 [html page]. https://www.autismspeaks.org/ autism-diagnosis-criteria-dsm- 5

Burkhart, L. (n. d.). ISAAC - What is AAC? https://isaaconline.org/english/what-is-aac.

CAST (2018). Universal design for learning guidelines version 2.2. http://udlguidelines.cast.org.

Cioè-Peña, M. (2015), Translanguaging within the monolingual special education classroom. CUNY Academic Common, IV. https://traue.commons.gc.cuny.edu/volume-iv-issue-1-fall-2015/ translanguaging-within-the-monolingual-specialeducation-classroom/

Colombia, Congreso de la República. (2013). Ley estatutaria 1618 de 2013. Author. http:// www.discapacidadcolombia.com/index.php/ component/phocadownload/category/2-publicaciones-legislacion?download $=6:$ ley-estatutaria 1618-de-2013

Crowe, S., Cresswell, K., Robertson, A., Huby, G., Avery, A. \& Sheikh, A. (2011). The case study approach. $B M C$ Medical Research Methodology, 11(100). https:// doi.org/10.1186/1471-2288-11-100

Cuadrado, T. (2006). Método TEACCH [Power Point Slides]. CEIP FOGAR. https://www.edu.xunta.gal/centros/ ceipfogarcarballo/system/files/TEACCH.pdf

Dzulkifli, M. A. \& Muhammad, F. M. (2013). The influence of colour on memory performance: A review. $\mathrm{Ma}$ lays J Med Sci, 20(2), 3-9. https://www.ncbi.nlm. nih.gov/pmc/articles/PMC3743993/

Hart. A. (2015). Ancient forms of communication in the spanish immersion classroom: The use of pictograms and rebuses to promote the development of spanish language literacy $[\mathrm{PDF}]$. CTI Fellow Collinswood Language Academy. https://charlotteteachers.org/wp-content/uploads/2016/02/ Adriana-Hart-_Origins-of-Language_2-11-16.pdf
Lashno, M. (n. d.). Sensory integration: Observations of children with Down syndrome and autistic spectrum disorders. https://www.kennedykrieger.org/stories/ sensory-integration-observations-children-downsyndrome-and-autistic-spectrum-disorders.

Lindsay, S., Proulx, M., Scott, H., \& Thomson, N. (2014). Exploring teachers' strategies for including children with autism spectrum disorder in mainstream classrooms. International Journal of Inclusive Education, 18, 101-122. https://doi.org/10.1080/13603116.2 012.758320

Lybarger, K. (2017). Effective teaching strategies for students with autism spectrum disorder and attention-deficit/ byperactivity disorder. https://www.vcccd.edu/sites/ default/files/departments/human-resources/sabbaticals/2017-2018/lybarger-monson-final_report.pdf

Migliaresi, G. (2018). Technology For Students With Special Educational Needs (SEN). https://www.primotoys. $\mathrm{com} /$ technology-for-students-with-special-educational-needs-sen/

Moreno, R., \& Durán, R. (2004). Do Multiple Representations Need Explanations? The Role of Verbal Guidance and Individual Differences in Multimedia Mathematics Learning. Journal of Educational Psychology, 96(3), 492-503. https://doi. org/10.1037/0022-0663.96.3.492

Moreno, R. \& Tejada, A. (2018). Atención a la diversidad e inclusión educativa: implicaciones didácticas. Colección iAccessibility. Universidad Rey Juan Carlos. https://sid.usal.es/idocs/F8/FDO27377/iAccessibility_15.pdf

Mulas, F., Ros, G., Millá, M., Etchepareborda, M., Abad,L., \& Téllez,M.(2010).Models of intervention for children with autism. Neurology Magazine, 50(S03), 77-84. https://doi.org/10.33588/rn.50S03.2009767

National Autistic Society. (n. d.). Strategies and interventions - TEACCH. https://www.autism.org.uk/advice-and-guidance/topics/ strategies-and-interventions/strategies-and-interventions/teacch\#: :text=The\%20TEACCH\%20 approach $\% 20$ tries $\% 20$ to, be $\% 20$ used $\% 20$ alongside\%20other\%20approaches

Pan, Y. (2009). Research on content-based working memory-driven capture of visual attention and its automaticity (in Chinese) [Doctoral dissertation]. Zhejiang University, Hangzhou, China.

Pan, Y.(2010). Attentional Capture by Working Memory Contents. Canadian Journal of Experimental Psychology, 64(2), 124-128. https://doi.org/10.1037/a0019109 
Pimentel, E., Castillo, M., \& Cuéllar, G. (2014). The gift of learning to teach. https://sites.google.com/site/ teachingtoteenangers/

Raising children.net.au. (n.d.). Treatment and Education of Autistic and related Communications Handicapped Children (TEACCH). https://raisingchildren.net.au/ autism/therapies-guide/teacch

Royal College of Speech and Language Therapists. (2019). Augmentative and alternative communication. https://www.rcslt.org/ speech-and-language-therapy/clinical-information/ augmentative-and-alternative-communication/

Ruiz, R. (2009). Sindrome de Down y logopedia. Cultiva Comunicación.

Shamir, A., \& Margalit, M. (2011). Technology and students with special educational needs: new opportunities and future directions. European Journal of Special Needs Education, 26(3), 279-282. https:// doi.org/10.1080/08856257.2011.593816

Sparapani, N., Morgan, L., Reinhardt, V. P., Schatschneider, C. \& Wetherby, A. M. (2016). Evaluation of classroom active engagement in elementary students with autism spectrum disorder. Journal of Autism and Developmental Disorders, 46, 782-796. https:// doi.org/10.1007/s10803-015-2615-2

Spaulding, L., Mostert, M., \& Beam, A. (2010). Is Brain $\mathrm{Gym}^{\circ}$ an effective educational interven- tion? Exceptionality, 18(1), 18-30. https://doi. org/10.1080/09362830903462508

Taylor, K. \& Preece, D. (2010). Using aspects of the TEACCH structured teaching approach with students with multiple disabilities and visual impairment: Reflections on practice. British Journal of Visual Impairment, 28, 244-259. https://doi. org/10.1177/0264619610374682

Steffie, V. D. S., Geveke, C. H., Steenbakkers, A. T. \& Steenbee, H. W. (2020). Teaching students with autism spectrum disorders: What are the needs of educational professionals? Teaching and Teacher Education, 90. https://doi.org/10.1016/j.tate.2020.103036

Vázquez, A. (2 de mayo de 2020). Gimnasia cerebral para problemas de aprendizaje [blog post]. https:// educpreescolar.blogspot.com/2020/05/gimnasiacerebral-para-problemas-de.html

Weller, D. (2019). Lesson planning for language teachers: Evidence-based techniques for busy teachers. Author.

Will, E., Fidler, D. J., Daunhauer, L., \& Gerlach-McDonald, B. (2016). Executive function and academic achievement in primary-grade students with Down syndrome. Journal of Intellectual Disability Research, 61(2), 181-195. https://doi.org/10.1111/jir.12313

World Health Organization. (2011). World report on disability. WHO. https://www.who.int/publications/i/ item/9789241564182

How to cite this article: Giraldo Martínez, Z. L., \& Ramos Carvajal S. A. (2021). Teaching English online to students with autism spectrum disorder and Down syndrome during the COVID-19 pandemic. Íkala, Revista de Lenguaje y Cultura, 26(3), 715-730. https://doi.org/10.17533.udea.ikala.v26n3a13 